\title{
Svinebugten 50 år efter
}

\author{
Jens Lohmann
}

\section{Invasionen i Svinebugten blev et ydmygende nederlag for USA og en triumf for cubanerne, der gjorde en tilnærmelse næsten umulig, men måske er der nu en åbning på vej}

Den 18. april 1961 rapporterede medier i USA, Latinamerika og Vesteuropa om en fremgangsrig invasion i Cuba vendt mod det revolutionære styre under Fidel Castro. Ifølge B.T., som slog begivenhederne i Cuba meget stort op, var de kontrarevolutionære invasionsstyrker, der var gået i land på Cubas sydkyst, nået et halvt hundrede kilometer ind i landet med retning mod Havana, samtidig med at bl.a. den store $\varnothing$ Isla de Pinos var blevet erobret og 8000 politiske fanger løsladt.

Få dage efter kunne B.T. i mindre opsætning meddele, at invasionen var slået fejl

Det tør siges den var slået fejl. At B.T. og andre medier i den vestlige verden i den grad kunne fejlinformere, hænger sammen med at den amerikanske efterretningstjeneste CIA, der organiserede invasionen, havde kalkuleret med fremgang for de 1297 eksilcubanske lejesoldater i invasionsstyrken, bl.a. takket være militær støtte fra amerikanske fly og krigsskibe, samt regnet med at den cubanske befolkning ville rejse sig mod det unge, revolutionære styre, hvis reformer, nationalisme og uafhængige kurs ikke behagede Washington. CIA havde udarbejdet et scenario og forfattet en række optimistiske bulletiner om invasionen, som blev tilsendt medierne gennem Lew Jones pr-bureauet i New York, på vegne af en cubansk eksilregering, som CIA havde sat sammen.

Invasionen i Cuba i april 1961 var et mønstereksempel på, hvad fejlinformationer, magtfuldkommenhed og blind tro på egen formåen, intern splittelse og magtkamp i den amerikanske administration, samt splittede og inkompetente cubanske eksilledere kunne føre til.

Invasionen 17.-19. april på Playa Girón-stranden og Bahía de Cochinos, Svinebugten, en forholdsvis øde 
strækning på sydkysten, 150 km sydøst for Havana, blev et forsmædeligt og ydmygende nederlag for verdens stærkeste militærmagt. Fidel Castro kunne triumferende i en timelang tv-transmitteret tale den 21. april i detaljer gennemgå invasionens forløb og fremhæve forsvarernes heltemodige indsats, fortælle cubanerne om revolutionens og folkets styrke, og sin vane tro, om udfordringer og problemer: "Vi mener, at folket har givet et ekstraordinært bevis: det har forsvaret sine rettigheder, det har forsvaret sin jord, det har forsvaret sin ære. Det har også vundet stor beundring verden over; det har opnået stor prestige, det har påført imperialismen et stort nederlag, det har udkæmpet en kamp for freden".

Han konstaterede også, at invasionen ville tjene til at forene cubanerne, som en ydre fjende ofte $\mathrm{g} ø \mathrm{r} . \mathrm{Og}$ til at styrke Fidel Castro og hans styre, kan man tilføje.

\section{Et problematisk naboskab}

Invasionen var en naturlig konsekvens af 150 års amerikansk interesse for og politik over for Cuba. Øens strategiske beliggenhed i forhold til USA og dens store økonomiske potentiale gjorde, at Washingtons blik hurtigt efter løsrivelsen fra Storbritannien blev rettet mod den velstående spanske koloni. Allerede i 1809 forsøgte USA forgæves at købe øen fra Spanien, ligesom man i 1803 havde købt det vidtstrakte Louisia- na-område fra Frankrig. Op gennem 1800-tallet blev der ført mange kampagner i USA for enten at annektere eller købe Cuba. Der blev samlet penge ind, og amerikanske udsendinge forhandlede igen og igen $\mathrm{i}$ Madrid.

I begyndelsen af 1898 tilbød præsident William McKinley den spanske dronning María Cristina 300 mio. dollar for øen, hvor cubanske oprørere siden 1895 havde trængt de spanske styrker tilbage. Dronningen var for at sælge, men blev stemt ned af regeringen.

Det fik McKinley til at gå ind i krigen mod Spanien, der hurtigt måtte overgive sig. Cuba blev besat af amerikanske styrker, og spanierne blev tvunget til en ydmygende fredsaftale i Paris i december 1898, hvor de måtte afstå Cuba, Puerto Rico, Filippinerne og de øvrige spanske besiddelser i Stillehavet. I Cuba var selvstændighedsbevægelsen for stærk og populær til, at USA ville risikere konstant uro. Så man tillod oprettelsen af en republik, som man påtvang en tilføjelse til forfatningen The Platt Amendment, vedtaget i den amerikanske kongres i 1901 som gav USA ret til at intervenere $\mathrm{i}$ Cuba, hvis man fandt, at amerikanske interesser var truet, samt ret til at oprette militære baser på cubansk grund på ubestemt tid og uopsigelige fra cubansk side. Guantánamobasen er et resultat af The Platt Amendment.

Cuba blev formelt selvstændigt i 
1902 efter at have underskrevet Platt Amendment. Det følgende halve århundrede blev præget af social uro, politiske konflikter og amerikanske invasioner. Frem til 1933 hørte militære landsætninger for at redde en regering eller beskytte amerikanske borgere og ejendom til cubanernes hverdag. I 1906, 1912, 1917 og 1933 fandt der større invasioner og besættelser sted.

I 1933 ophævede Franklin Roosevelt The Platt Amendment som led i sin nye 'Gode Naboskabs' politik over for Latinamerika, som afløste forgængeren, den fjerne fætter Theodore Roosevelts 'Store Stoks' politik, der frem til 1933 indebar adskillige amerikanske invasioner $\mathrm{i}$ Mellemamerika og Caribien især.

Den gode nabos politik betød dog på ingen måde, at USA holdt op med at intervenere i latinamerikanske landes anliggender. Direkte militære interventioner, invasioner og besættelser blev afløst af hemmelige operationer i samarbejde med lokale politikere og militær støtte til kup og til militærregeringer.

Den amerikanske interesse for Cuba forblev uformindsket, ikke mindst på grund af store amerikanske investeringer i bl.a. sukkerindustrien, infrastrukturen og turismen, samt øens strategiske beliggenhed.

Under Anden Verdenskrig holdt USA lav profil i Latinamerika, hvor nationale og sociale bevægelser, bl.a. inspireret af den store mexicanske revolution 1910-19, havde fået bred tilslutning mange steder. Nationalistiske tendenser og sympati for Mussolinis og Francos fascisme, især i mange landes militær, og nogle steder også tætte bånd til Tyskland og Italien skabte frygt for, at lande som Argentina, Bolivia, Chile, Paraguay, Colombia og Brasilien skulle gå ind i krigen på Aksemagternes side.

Roosevelt iværksatte en charmeoffensiv med kulturfremstød, hvor Disney var den mest fremtrædende del med tegnefilm som Saludos Amigos (1941) og The Three Caballeros (1945) samt adskillige tegnefilm med Anders And og Mickey Mouse på besøg i Sydamerika. Det gav pote. I befolkningen ændrede billedet af USA sig, samtidig med at sympatien for de trængte Aksemagter svandt. De fleste lande holdt sig neutrale indtil 1945, da de nærmest symbolsk gik ind i krigen på de allieredes side. Enkelte lande erklærede dog Aksemagterne krig tidligere og gik ind i krigen med få fly eller skibe. Brasilien deltog fra 1942 med 25.000 mand.

\section{Den Kolde Krig}

Krigen betød, at Storbritanniens store indflydelse i Latinamerika blev reduceret, og USA blev den absolut dominerende magt på kontinentet. Man ønskede at konsolidere den amerikanske indflydelse og udbrede amerikanske værdier om demokrati og livsform. Det betød, at de mange diktaturer var uønskede - selv om 
flere af dem havde været støttet fra Washington.

Samtidig frygtede USA, at den kommunistiske indflydelse skulle vokse. Sovjetunionen havde vundet stor respekt og sympati i brede kredse under krigen, og i flere lande var kommunistpartierne vokset. Under og efter krigen faldt flere af de USAstøttede diktaturer, ofte efter kup fra yngre officerer, og blev afløst af demokratisk valgte regeringer, flere af dem reformorienterede (Guatemala, El Salvador 1944) og/eller populistisk-nationalistiske (Argentina 1946). Fra amerikansk side så man med bekymring på de reformistiske og nationalistiske tendenser. I Argentina havde USA aktivt forsøgt at hindre valget af den nationalistiske, tidligere Mussolini-beundrer, oberst Juan Domingo Perón i 1946. Forgæves. Perón red på en bølge af popularitet, der blev styrket af gennemgribende sociale reformer.

For at dæmme op for den kommunistiske fremgang tog USA i 1948 initiativ til at oprette Organisationen af Amerikanske Stater, OAS, hvis erklærede mål var at fremme og beskytte demokratiet på den vestlige halvkugle, samt fremme det regionale samarbejde og forsvare medlemsstaterne mod aggression udefra. Det blev hurtigt klart, at forsvaret mod ydre fjender (underforstået Sovjetunionen og allierede) også omfattede indre fjender som kommunistiske partier og andre, mere eller mindre venstreorienterede eller blot moderat reformorienterede kræfter. I flere lande blev de lokale kommunistpartier forbudt efter amerikansk pres.

Et middel mod disse reelle og indbildte fjender skulle være militæret. I 1946 oprettede USA en særlig skole til uddannelse af latinamerikanske officerer, School of the Americas, i den USA-styrede Panama Kanalzone. Officererne fik både teoretisk og praktisk undervisning i bekæmpelse af interne oprør, og kun i mindre grad i forsvar mod angreb udefra. Adskillige senere militærdiktatorer i Latinamerika blev uddannet på School of the Americas.

Foruden den militære bistand begyndte USA også at give politimæssig bistand for at styrke den indre sikkerhed. Den nye amerikanske efterretningstjeneste, CIA, fik Latinamerika som et vigtigt operationsområde. Latinamerikanske politifolk blev sendt på kurser i USA for at lære de nyeste metoder i efterforskning og efterretning - samt afhøring, hvilket viste sig bl.a. at omfatte torturmetoder.

Flere af de demokratiske regeringer faldt igen i årene frem til midten af 1950'erne og blev afløst af hårdhændede diktaturer - bl.a. i El Salvador, Venezuela, Guatemala og Cuba. Især omstyrtelsen af Guatemalas moderate reformregering under den demokratisk valgte Jacobo Arbenz i 1954 fik langtrækkende virkninger i regionen. Da Arbenz indledte en landbrugsreform ved at eks- 
propriere ubenyttet jord fra det amerikanske United Fruit Company, iværksatte Eisenhowers regering en række økonomiske indgreb over for landet samt standsede alt salg af våben og militært udstyr. Et skib med lette våben og ammunition fra det kommunistisk styrede Tjekkoslovakiet blev standset af amerikanske krigsskibe - og set som 'bevis' på at Guatemala var ved at blive overtaget af kommunisterne.

Kulminationen blev en blodig CIA-organiseret invasion under ledelse af en stærkt højreorienteret eksiloberst, Carlos Castillo Armas, der indledte en brutal heksejagt på den styrtede regerings tilhængere. Det var indledningen på årtiers blodig undertrykkelse og en borgerkrig, som formelt sluttede med en fredsaftale i 1996.

\section{Revolutionen og USA}

\section{Da Fidel Castro og hans partisaner} rykkede ind i Havana lige efter nytår 1959, var de forberedt på, at deres reformprojekt kunne møde modstand både i USA og Cuba, selv om langt de fleste cubanere umiddelbart støttede de nye magthavere.

Castro var fortrolig med forholdene i Latinamerika. Hans højre hånd, argentineren Ernesto 'Che' Guevara havde været i Guatemala under Arbenz, hvor han oplevede invasionen og kuppet, og med nød og næppe slap ud af landet. De nye ledere i Cuba var klare over risikoen ved at gennemføre sociale og økonomiske reformer, der var andet end en fernis til at legitimere styret udadtil og bevare de hidtidige forhold med store sociale og økonomiske forskelle, racediskrimination og udenlandsk dominans af økonomien.

Belært af den konstante amerikanske indblanding i Cubas indre anliggender - bl.a. USA's støtte til diktatoren Batista helt frem til en måned før Castros sejr - og af især Guatemala i 1954, handlede Castro hurtigt. Den første landbrugsreform - som ikke var særlig radikal sammenlignet med bl.a. den mexicanske fra 1916 og frem, og den bolivianske fra 1953 - blev indledt i maj 1959. Ejendom, der tilhørte Batista og hans tilhængere, blev hurtigt nationaliseret. En ambitiøs byreform med både nybyggeri og omfordeling af boliger til de dårligst stillede blev iværksat. Cubanere - fortrinsvis fra den mere velstående del af befolkningen - som forlod landet, fik deres ejendom konfiskeret. Også cubansk og amerikansk ejede virksomheder af alle slags samt banker blev eksproprieret i 1960. Det nye styre udfordrede desuden USA ved at søge nye handelspartnere (hidtil var over 90 pct. af Cubas udenrigshandel foregået med USA).

Kursen over for USA virkede selvmorderisk. Men Castro nøjedes ikke med at ekspropriere og reformere. Han agiterede, organiserede og mobiliserede dygtigt. Han drog ud i de mest afsides hjørner af landet for at 
mødes med folk og sætte projekter i gang, ikke mindst blandt fattigbønder og arbejdere, med støtte fra studerende, kunstnere og intellektuelle, der fik masser af muligheder for at ytre sig og være kreative.

I takt med reformerne og ekspropriationerne begyndte den første modstand, bl.a. i form af sabotager og modpropaganda med støtte fra USA. I løbet af 1960 angreb fly bemandet med eksilcubanere og udrustet af CIA sukkerrørsmarker med brandbomber for at ødelægge Cubas vigtigste indtægtskilde, sukkeret. I marts 1960 blev det franske skib La Coubre, der var lastet med belgisk ammunition, ødelagt af to eksplosioner i Havanas havn. Mindst 75 mennesker mistede livet. Styret anklagede straks CIA for at stå bag eksplosionerne. Det er muligt, men det er uvist, hvad der forårsagede den.

I det spændte klima mellem Cuba og USA var det dog ikke vanskeligt at overbevise cubanerne om, at $\mathrm{La}$ Coubre var CIA's værk. Eksplosionen blev dygtigt anvendt af Castro og hans styre til at mobilisere befolkningen, bl.a. i væbnede militser og Komiteerne til Forsvar for Revolutionen.

Den landsomfattende kampagne mod analfabetisme, der blev indledt i januar 1961 med deltagelse af omkring 100.000 fortrinsvis unge mennesker, var både et seriøst skridt i retning af at udrydde analfabetismen og et tiltag til at vise de fattigste, at dette også var en revolution for dem, ikke bare retorik og varm luft.

\section{Et forsmædeligt nederlag}

Regeringen mobiliserede med andre ord dygtigt mod det angreb fra USA-støttede eksilcubanere, som den belært af eksemplet fra Guatemala regnede med ville komme. Det overraskende var, at CIA i sin planlægning af invasionen - som begyndte et år tidligere - syntes at have taget afsæt i en ønskevision af Cuba, hvor man mente, at støtten til Castro var faldet fra 95 pct. af befolkningen til 25-33 pct. Ligeledes er det overraskende, at man regnede med, at det valgte invasionssted, Svinebugten på sydkysten, var næsten uforsvaret, og at de cubanske militser og regeringsstyrker ikke ville være i stand til at rykke frem og forhindre landsætningen.

CIA syntes også at stole på, at den brogede invasionsstyrke - der var blevet trænet i de USA-støttede diktaturer Guatemala og Nicaragua, og som sejlede fra Puerto Cabezas i Nicaragua - var så veltræenet 'som de bedste hære i Latinamerika', således som CIA hævdede over for regeringen. En sandhed med store modifikationer. Mange af lejesoldaterne havde kun få ugers træning bag sig

Men Cuba var ikke Guatemala. Stærkt motiveret og gennemgående effektiv cubansk modstand kunne i løbet af to døgn nedkæmpe en dårligt organiseret og demoraliseret 
styrke af eksilcubanske lejesoldater, der ikke fik den luftstøtte fra amerikansk side, de var blevet stillet i udsigt.

Resultatet blev ikke blot et forsmædeligt nederlag og en national og international ydmygelse af præsident John F. Kennedy og hans regering. Ydmygelsen blev kraftigt understreget under et langt, direkte tvtransmitteret forhør af de tilfangetagne lejesoldater i cubansk tv fire aftener i træk.

Virkningerne af den mislykkede invasion var især store og langtrækkende i Latinamerika. Først og fremmest betød Svinebugten en kolossal sejr og prestige for Fidel Castro og den cubanske revolution. Ikke at latinamerikanske regeringer sluttede op om det cubanske styre. De fleste latinamerikanske lande afbrød efterhånden de diplomatiske og økonomiske forbindelser med Cuba efter pres fra USA. Kun Mexico, Ecuador, Chile og Brasilien holdt stand. Brasilien faldt fra, da militæret med USA's støtte i 1964 afsatte den demokratisk valgte, populistiske reformpræsident João Goulart. Så faldt Chile og Ecuador fra, og kun Mexico fastholdt forbindelserne.

\section{Støtte til oprørsbevægelser}

Til gengæld begyndte Castro at gøre alvor af sine ord fra den 3. januar 1961, da præsident Eisenhower afbrød de diplomatiske forbindelser.
Med henvisning til Eisenhowers beslutning og stadig flere sabotager og flyangreb sagde Castro, at "hvis De Forenede Stater mener det har ret til at fremme kontrarevolution $\mathrm{i}$ Cuba og til at fremme kontrarevolution i Latinamerika, så har Cuba ret til at fremme revolutionen i Latinamerika".

Castro så støtte til revolutionære kræfter i Latinamerika som en livsnødvendighed for den cubanske revolution, efter at Cuba var blevet næsten totalt politisk og økonomisk isoleret på den vestlige halvkugle.

Revolutionære fra hele Latinamerika begyndte at strømme til Cuba for at blive trænet i guerillakrigsførelse. Cubanernes erfaringer fra oprøret mod Batista 1956-58 udmøntede sig i en opfattelse, som fik sit klareste udtryk i Che Guevaras lille håndbog om guerillakrig, La guerra de guerrillas, og i franskmanden Régis Debrays teoretiske tolkning i bogen Revolution i revolutionen?, som han skrev under cubansk vejledning.

Kort fortalt gik strategien ud på at oprette brændpunkter med oprørsgrupper uden for byerne. De skulle efterhånden brede sig, omringe byerne og i koordination med oprørere i byerne indtage disse og til slut tage kontrol over landet. I løbet af 1960'erne blev der dannet adskillige guerillagrupper i Latinamerika efter denne model, de fleste med direkte cubansk støtte. Næsten alle slog fejl og blev nedkæmpet, bl.a. den bevæ- 


\section{BAGGRUND}

gelse, som Guevara selv satte sig i spidsen for i Bolivia i 1966. I oktober 1967 blev han fanget og henrettet af bolivianske soldater.

Var guerillaerne generelt en fiasko, var de med til at sætte den politiske dagsorden i Latinamerika, og tidligere guerillaer - også ikke-Castro-orienterede - gik flere steder ind i politik, fra El Salvador til Brasilien. Brasiliens nye præsident Dilma Roussef var under militærdiktaturet således aktivt medlem af en byguerillagruppe. Tidligere guerillabevægelser i bl.a. Guatemala og El Salvador spiller i dag en central politisk rolle. I El Salvador er den således regeringsparti. Kun en af de cubansk støttede guerillabevægelser kom til magten gennem sin væbnede kamp efter cubansk mønster, men også gennem alliancer med moderate kræfter. Det var den nicaraguanske sandinistbevægelse, der smed det gamle, USA-støttede Somoza-diktatur på porten i 1979.

Invasionen i Svinebugten var med til at kaste Cuba i armene på Sovjetunionen - netop det som Washington havde beskyldt Castro for inden invasionen. Cuba havde al mulig grund til at frygte et nyt og mere effektivt angreb fra USA. Solidaritet fra venstrefløjen i Latinamerika ville intet kunne stille op over for en sådan invasion. Guerillabevægelserne ville i bedste fald først kunne blive en væsentlig militær faktor, der kunne binde amerikanske styrker, i løbet af nogle år.
Sovjetunionen viste sig villig til at yde omfattende militær hjælp, bl.a. som svar på USA's militære baser tæt på Sovjetunionen (bl.a. i Vesttyskland, Tyrkiet og Pakistan). Det varede ikke længe, før Sovjetunionen på cubansk anmodning begyndte at anlægge missilbaser i Cuba. I 1962 blev anlæggene fotograferet af amerikanske spionfly, og da sovjetiske skibe med missiler ombord på vej til Cuba blev opdaget, udløste det i oktober samme år den alvorligste krise mellem de to supermagter nogensinde. Det lykkedes at afværge en åben konflikt. De sovjetiske skibe blev tvunget til at vende om trods cubanernes heftige protester.

Cuba følte sig svigtet af Sovjetunionen, lagde afstand til Moskva og nærmede sig Kina. Desuden gjorde Cuba en dyd af nødvendigheden og gav deltagelsen i Sammenslutningen af Alliancefrie Lande meget høj prioritet. For at skaffe sig handelspartnere - for ikke at blive alt for afhængigt af Sovjetunionen og Østblokken - og for at bryde den isolation, det var kommet i i Latinamerika, udviklede Cuba et meget aktivt og effektivt globalt diplomati og blev en meget aktiv spiller i FN. Altid med USA som hovedmodstander. USA strammede på sin side den økonomiske blokade mod Cuba og gav omfattende støtte til eksilcubanske grupper, der gennemførte væbnede operationer fra Florida.

Indadtil strammede styret kursen i løbet af 1960'erne. Den frie debat, 
der havde præget de første år af revolutionen, blev gradvist indskrænket. Så da Fidel Castro i august 1968 til manges overraskelse tilsluttede sig Warszawapagtlandenes invasion af Tjekkoslovakiet betød det en betingelsesløs tilslutning til Sovjetblokken og en definitiv lukning for åben politisk diskussion og ytringsfrihed i Cuba.

I 1972 blev Cubas nære tilknytning til og afhængighed af Sovjetunionen beseglet med Cubas indtræden i den østlige, økonomiske samarbejdsorganisation COMECON. Det betød garanterede leverancer af billig olie, maskiner og udstyr, samt afsætning af cubanske varer som sukkerrør, kaffe, tobak og appelsiner.

Desuden blev Cuba en vigtig militær allieret og delvis stedfortæder for Sovjetunionen i Afrika. Det gjaldt især i Etiopien, hvor Cuba gik ind på etiopisk side i Ogaden-krigen mod Somalia 1977-78 og var med til at sikre Etiopiens sejr. I Angola engagerede Cuba sig på befrielsesbevægelsen MPLA's side mod det portugisiske kolonistyre allerede i 1963. Fra uafhængigheden i 1975 var Cuba massivt til stede i Angola både militært og civilt. I alt var 430.000 cubanske bistandsarbejdere aktive i Angola frem til 1991, da krigen mod Sydafrika og de USA-støttede oprørsbevægelser sluttede, og Sovjetunionen brød sammen.

Allerede med Gorbatjovs perestrojka fra 1986 blev den sovjetiske støtte til Cuba kraftigt reduceret. Fra 1991 ophørte den totalt, og Cuba var på randen af økonomisk sammenbrud. Det kan forekomme mirakuløst, at landet klarede sig igennem den kritiske período especial, specialperioden 1991-95, med økonomiske restriktioner og mangel på alt. Det skyldes formentlig en kombination af stædighed - cubanerne ville ikke 'overgive' sig til USA frygt for eksilcubanernes revanchisme hvis de vendte tilbage, $\varnothing$ konomiske lempelser og hårdhændet undertrykkelse fra styret, samt en voksende økonomisk og politisk åbning fra flere latinamerikanske lande.

\section{Latinamerikansk åbning}

Den nye venstredrejning og nationalisme i store dele af Latinamerika efter årtusindskiftetbetød, at Cuba blev lukket helt ind i det latinamerikanske selskab - bl.a. gennem det nye regionale samarbejde, der tegner sig i disse år som alternativ til OAS, der også omfatter USA og Canada.

I 2009 vedtog OAS' generalforsamling enstemmigt at ophæve den 47 år gamle suspendering af Cubas medlemskab. Beslutningen var en stor sejr for Cuba og et signal fra Obama-regeringen om at man ønsker at normalisere forholdet mellem de to lande, utvivlsomt også efter kraftigt pres fra toneangivende latinamerikanske lande. Cuba har dog gentagne gange kategorisk af- 
vist at genindtræde i OAS.

Barack Obama og Hillary Clinton har tydeligvis erkendt, at tiden er inde til at revidere USA's forhold til de latinamerikanske naboer. En af de store hindringer på vejen er forholdet til Cuba. Efter nederlaget ved midtvejsvalget i november 2010, der gav Republikanerne flertal i Repræsentanternes Hus, er det blevet vanskeligere. Den eksilcubanske lobby har en betydelig indflydelse i Det Republikanske Parti, men den nyder ikke længere så bred støtte blandt eksilcubanerne som tidligere. Et halvt århundredes uforsonlighed over for Cuba har ikke givet pote. Samtidig presser amerikanske virksomheder på for at få ophævet blokaden, så de kan komme til at gøre forretninger i det Cuba, de betragter som et naturligt virkeområde og som europæiske og latinamerikanske konkurrenter har sat sig på gennem årene takket være blokaden.

Obama har allerede foretaget enkelte lempelser over for Cuba, og flere vil komme i takt med, at han arbejder på at forbedre relationerne med Latinamerika. Hans rundrejse til Brasilien, Chile og El Salvador i marts var nøje afstemt: besøg i regionens $\varnothing$ konomiske og politiske sværvægter Brasilien, i det hidtidige politiske og økonomiske mønsterland Chile og i den lille, mangeårige tro- faste allierede El Salvador, hvor den tidligere guerillabevægelse FMLN ad demokratisk vej har afløst det stærkt proamerikanske højre ved magten. Præsident Mauricio Funes kan tjene som et godt bindeled til et cubansk styre, der står i en voldsom $\varnothing$ konomisk krise, som det forsøger at komme ud af ved hjælp af radikale indgreb, bl.a. massefyringer af offentligt ansatte.

Den cubanske revolution blev for USA et dybt traume. USA's lederskab og værdier blev ikke kun draget i tvivl og udfordret i ord, men i høj grad i handling. Det kunne datidens amerikanske ledere ikke acceptere eller tilgive. Da de greb til gammelkendte midler for at tvinge de formastelige til at bøje sig, gik det galt. Efter invasionen i Svinebugten var ingen tilnærmelse mulig. Konflikten eskalerede i en uendelig spiral.

Med Barack Obamas nye tilgang til omverdenen, herunder Latinamerika, det kriseramte Cubas akutte behov for $ø$ konomisk bistand og en cubansk regering, der sidder på en tikkende social og politisk bombe, er der nye muligheder for tilnærmelse og forsoning uden at nogen af parterne taber ansigt.

Jens Lohmann er journalist og forfatter, specialist i latinamerikanske forhold. 